\title{
Characters and Narrators in Narrative Communication: James Phelan's Rhetorical Poetics of Narrative
}

Jakob Lothe

University of Oslo, Norway

There are several reasons why James Phelan's contributions to narrative theory have proved, and continue to prove, influential. One of the reasons is suggested by the way in which, adopting and developing a rhetorical perspective, he shows that narrative is a powerful mode of exploration and communication. Linked to, and in actual fact inseparable from, this reason for the significance of Phelan's work is a critical practice that is pluralistic rather than dogmatic, engaging in and furthering conversations with other scholars rather than defending a given position at all costs. This kind of critical open-mindedness and generosity is connected with Phelan's readiness to test his concepts and theories by using them in narrative analysis. If he finds that there are important aspects of a given narrative - for example, Kafka's "Das Urteil" (Phelan, "Progression") - that his rhetorical approach to narrative cannot adequately explain, the story's interpretive challenge inspires him to modify and refine his version of rhetorical narrative theory.

Since the target essay by Phelan under consideration here is very rich, I will concentrate on his discussion of character, but I will link my observations on that concept to that of narrator. I will illustrate my points by briefly discussing the intricate ways in 
which the narrative functions and thematic implications of character and narrator blend into and mutually reinforce each other in W. G. Sebald's Austerlitz (2001).

As Phelan acknowledges, the demonstration of the need to distinguish between the author of a fictional narrative and the narrator or narrators in that narrative was an important achievement of early narrative theory. Later disagreement about the terms we use in order to differentiate between different kinds of narrators should not prevent us from recognizing the critical gain stemming from this distinction. Yet it does not follow that the concept of the narrator is unproblematic. One of the problems is, as Phelan rightly notes in the target essay, that narrative theorists' focus on the narrator has tended to distract attention from the important concept of character.

Rhetorical narrative theory agrees with classical narratology that the concept of the narrator is indispensable. In Living to Tell about It, Phelan defines the narrator as "the teller of the story" (217). That his understanding of the narrator is different from that of classical narratology, however, becomes clear once we link this definition to that of narrative "as a rhetorical act: somebody telling somebody else on some occasion and for some purpose(s) that something happened" (18). This definition is also Phelan's startingpoint in the target essay. His understanding of the implied author not as a voiceless "it" or a set of implicit norms, but as "the streamlined version of the real author responsible for the construction of the text" (Living, 5) also colors his understanding of the narrator, as does his interest in the authorial audience and the emphasis on narrative's ethical dimension.

In Living to Tell about It as in Experiencing Fiction, Phelan locates the implied author outside the narrative text. He does so in the target essay too, emphasizing "the 
author/implied author as a constant" and drawing attention to "the overarching issue of how the implied author uses the various resources of narrative communication at her disposal" (10). Partly as a result of my interest in narrative ethics, I am inclined to agree with this view. I would like to add, though, that regardless of whether the audience locates the implied author inside or outside the text, our knowledge and evaluation of the implied author is entirely dependent on our reading of the text. Thus, there is a sense in which the implied author, though positioned outside the text, is also within it. An unread novel has an author; a novel once read has an author and an implied author.

In the target essay, Phelan emphasizes the implied author's key role in narrative communication even more strongly than in Living to Tell about It and Experiencing Fiction. One reason why he does this is that, dissenting from the standard view of classical narratology, he considers the narrator as just one out of several "resources" on which an author can draw in narrative communication. Thus, a number of the functions that classical narratology ascribes to the narrator are subsumed under, or included in, the implied author's domain.

As Phelan's chart of constants and variables in narrative communication makes clear, one of these resources is character. Since the exclusion of character from Seymour Chatman's communication model (a model used in many studies of and introductions to narrative, including my own Narrative in Fiction and Film) is not only conspicuous but theoretically untenable, the inclusion of character in the chart is a considerable critical gain. This is particularly evident in first-person narratives.

While the inclusion of character as a narrative resource in the chart is a significant improvement on Chatman's model, and while it is an attractive feature of the chart that it 
deliberately does not claim to cover all the resources authors can activate in order to communicate their narratives (e.g., the term perspective could helpfully be added), the way in which very different resources are gathered in one column is not unproblematic. There are two linked issues here. First, as indicated already, some of the resources are more important than others. While narrator(s) and characters are indispensable resources, I am not sure that paratexts is, and there are narratives that make limited or no use of FID. Second, the resources are different in kind. In one sense this is one of the chart's strengths, since narrative resources are remarkably diverse. And yet, while the resource of, for example, temporality is a fundamental condition of all narrative communication, that of arrangements/gaps refers to ways in which that dimension is represented by, and presented in, narratives.

A considerable gain of Phelan's chart is that, compared to Chatman's communication model, it is much less uni-directional. The following observations on Sebald's Austerlitz will illustrate this gain, and this narrative text is also illustrative of the interplay of the narrative resources of narrator and character. Austerlitz tells the story of the fictional character Austerlitz's belated search for his childhood and his parents, who were Jews and were in all probability murdered by the Nazis. Details of Austerlitz's origin have been suppressed for a long time; it has taken him a lot of time and energy to find out that although he grew up in a Welsh village, he is actually a Czech Jew who was sent to Britain when he was only five, on a Kindertransport in 1939.

The novel begins thus: 
In the second half of the 1960s I travelled repeatedly from England to Belgium, partly for study purposes, partly for other reasons which were never entirely clear to me, staying sometimes for just one of two days, sometimes for several weeks. On one of these Belgian excursions which, as it seemed to me, always took me further and further abroad, I came on a glorious summer's day to the city of Antwerp, known to me previously only by name. (1)

On a first reading, we may think that the first-person narrator, the "I" who travels "repeatedly from England to Belgium," is identical with Austerlitz - and also with the boy on the book's front cover. Yet this beginning is actually a frame narrative whose function is to establish a narrative situation in which the two can meet, and in which Austerlitz can talk: "One of the people waiting in the Salle des pas perdus was Austerlitz, a man who then, in 1967, appeared almost youthful, with fair, curiously wavy hair ..." (6).

This is the first mention of Austerlitz's name, or more accurately, the first repetition of the name we have read on the book's cover. Austerlitz is presented as a traveler, and yet one who stands apart from the others. He tells tales, or rather fragments of tales, which make an impression on the frame narrator as narratee. By telling fragments of his story Austerlitz risks confirming his sense of loss and estrangement, yet his narration may enable him to negotiate that loss. By listening, the narratee, who turns out to be an exiled German, risks being confronted with horrible events, yet the fact that he not only listens to but also retells what Austerlitz has told him suggests a significant learning process. 
Although the narrative situation is constituted by Austerlitz as narrator and the exiled German as a narratee who then imparts the whole story to the reader, the narrative exchange is dependent on, and proceeds from, their qualities as characters. Importantly, this kind of quality is not limited to the distinctive features of a given character - not even as he or she is presented in the narrative discourse. Rather, "qualities" here refers to the ways in which aspects of character blend into, and thus serve to constitute, the narrative communication. Appropriating Phelan's terms in the target essay, the "authornarrator-audience" complex typically identified and discussed by classical narratology is supplemented, and in one sense even conditioned, by an "author-character-characteraudience" constellation consisting of Austerlitz and the frame narrator: the novel's two main characters who, because they are a Jew who survived the Holocaust and an exiled German probably born in the last year of the war, become engaged in an extended narrative exchange whose ethical dimension remains insistent throughout.

While I agree with Phelan that an author can use more than one channel of communication, and while I also concur that there is a synergy effect between the channels, I am not sure that the channels need to be functionally independent. They may be so in William Faulkner's The Sound and the Fury, on whose brilliant beginning Phelan makes perceptive comments. Yet in Austerlitz, there is a striking reciprocity of not just narrator and narratee but also of two individuals associated with the inflicting and receiving of horrific wrong in the recent past. If the motives for the narration depend on Austerlitz's and the exiled German's character qualities, these qualities are presented to the reader through the narrative acts they perform. That character plays a key role in narrative communication does not make the narrator less important. In Austerlitz, the 
interplay of these two key components of narrative communication is particularly well illustrated by the novel's narrative ethics, which demonstrate that interpretation is in this case both the reader's and, inside the text, a product of Austerlitz's and the frame narrator's interpretive efforts. Austerlitz is a forceful illustration of Hans-Georg Gadamer's point that interpretation is "not merely a reproductive but always a productive activity as well" (296). If, as Paul Ricoeur convincingly argues, no narrative is "ethically neutral" (140), neither is there an ethically neutral reading. Or, in Phelan's terminology, textual dynamics and readerly dynamics are interdependent. The interplay of narrators, characters, and readers contributes significantly to narrative's unique ability to shape, in Hanna Meretoja's phrase, "our view of who we are and who we could become" ("Narrative Hermeneutics").

\section{Works Cited}

Gadamer, Hans-Georg. Truth and Method (Wahrheit und Methode, 1960), 2nd ed., trans.

Joel Weinsheimer and Donald G. Marshall. New York: Continuum, 1997.

Meretoja, Hanna. "Narrative Hermeneutics and the Ethical Potential of Literature.” In

The Future of Literary Studies, ed. Jakob Lothe. Oslo: Novus Press, 2017, 135-47.

Phelan, James. Living to Tell about It: A Rhetoric and Ethics of Character Narration. Ithaca: Cornell University Press, 2005. 
Phelan, James. Experiencing Fiction: Judgments, Progressions, and the Rhetorical Theory of Narrative. Columbus: Ohio State University Press, 2007.

Phelan, James. "Progression, Speed, and Judgment in 'Das Urteil.'” In Franz Kafka: Narration, Rhetoric, and Reading, ed. Jakob Lothe, Beatrice Sandberg, and Ronald Speirs. Columbus: Ohio State University Press, 2011, 22-39.

Ricoeur, Paul. Oneself as Another (Soi-même comme un autre, 1990), trans. Kathleen Blamey. Chicago: University of Chicago Press, 1992.

Sebald, W. G. Austerlitz, trans. Anthea Bell. London: Penguin Books, 2002. 